\title{
PAFAH1B1 wt Allele
}

National Cancer Institute

\section{Source}

National Cancer Institute. PAFAH1B1 wt Allele. NCI Thesaurus. Code C75886.

Human PAFAH1B1 wild-type allele is located in the vicinity of 17p13.3 and is

approximately $92 \mathrm{~kb}$ in length. This allele, which encodes platelet-activating factor acetylhydrolase, isoform Ib, alpha subunit protein, plays a role in the regulation of neuronal migration. Mutations in the gene are associated with lissencephaly type 1, subcortical band heterotopia, and Miller-Dieker lissencephaly syndrome. 